\title{
ДВАТА ПОЛА НА КНИЖЕВНАТА ПРОДУКЦИЈА: ХЕТЕРОНОМИЈАТА, АВТОНОМИЈАТА И КНИЖЕВНОТО ПОЛЕ ВО ТЕОРИЈАТА НА ПЈЕР БУРДЈЕ
}

\author{
Ведран Диздаревиќ \\ Универзитет „Св. Кирил и Методиј“, Скопје \\ vdizdarevic@yahoo.com
}

Книжевниот свет отсекогаш го обележувале дебати за легитимноста на книжевните дела. За ког̄o се пишува, за кого йреба да се пишува, како да се пишува и ред други прашања од овој вид се повторуваат со статистичка регуларност, особено од осамостојувањето на книжевноста како авйономно йоле на крајот на XVIII и почетокот на XIX век. Во овој труд, преку примерите на два конфликта од тој вид - критиките на Пауло Коелјо и на Х. Џ. Велс кон Улис и Боеењетио на Финеган од Џејмс Џојс и спротивставените ставови на поетот критичар Т.С. Елиот - ќе го анализираме значењето на овој вид конфликти за полето на книжевноста. Во анализата главна методолошка алатка ќе ни бидат теориите на францускиот социолог Пјер Бурдје, особено неговиот концепт за йоле и, специфично, за йолетио на кни-

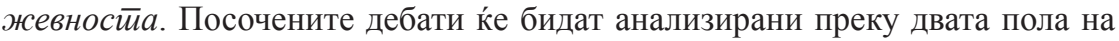
функционирањето на книжевното поле: книжевната йрояукиија со мал ой-

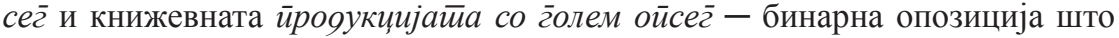
логично произлегува од двојната хиерархизација на полето. Според Бурдје, конфликтите од овој вид произлегуваат од самата структура на книжевното поле како такво и помагаат во неговото легитимирање како автономен модус на културна продукција, неговата продукција и репродукција во рамките на општествената стварност.

Клучни зборови: книжевна дебата, Пјер Бурдје, поле, комерцијална литература, културна продукција, книжевно поле 


\title{
THE TWO POLES OF LITERARY PRODUCTION: HETERONOMY, AUTONOMY AND THE LITERARY FIELD IN THE THEORY OF PIERRE BOURDIEU
}

\author{
Vedran Dizdareviќ \\ Ss. Cyril and Methodius University, Skopje \\ vdizdarevic@yahoo.com
}

The literary world has always been marked by the debate on the legitimacy of literary works. Who the literary works are written for, who they should be written for, and how one should write them. Additionally, a plethora of other similar questions have been raised, time and time again, with statistical regularity, especially after the establishment of literature as an autonomous field at the end of the 18 th and the beginning of the 19th century. In this paper, the importance of this type of conflict in the field of literature will be analyzed by examining two such instances in literature - Paulo Coelho and H.G. Wells' criticism of Ulysses and Finnegan's Wake by James Joyce and the contrasting views of the poet and critic T.S. Eliot. Pierre Bourdieu's theories will serve as our main methodological tool in this analysis, particularly his concept of field, specifically addressing the literary field. We will further analyze the indicated examples by opposing the two poles of functioning of the literary field: restricted production and large-scale production - a binary opposition that logically stems from the dual hierarchization of the field. According to Bourdieu, conflicts of this kind stem from the very structure of the literary field itself, and help legitimize it as an autonomous module of cultural production as well as drive its production and reproduction within societal reality.

Keywords: literary debate, Pierre Bourdieu, field, commercial literature, cultural production, literary field 


\section{1 Вовед}

Книжевните дебати во однос на легитимноста на книжевните дела како уметнички дела се константа во светот на уметноста и на литературата. Целта на овој труд ќе биде да дадеме свежа перспектива на овој книжевен и културолошки феномен, од аспект на социологијата на литературата. Имено, ќе покажеме дека книжевните дебати и конфликтите во „уметничкиот универзум“ не се воопшто арбитрарни, туку имаат свои правила и регуларности; или, со други зборови, дека можат да бидат проучувани од научна гледна точка. Во овој труд ќе му пристапиме на проблемот преку анализа на два кратки извадока од писателите Пауло Коелјо и Х. Џ. Велс, насочени кон намалување на вредноста на делата на Џејмс Џојс и еден коментар на поетот Т. С. Елиот, кој, од друга страна, се обидува да ја потенцира вредноста на романот Улис. Во првото поглавје ќе ги анализираме овие два примера, првин преку анализа на изјавата на Коелјо во бразилскиот весник Фолја gе С. Паоло пренесена во Гаряијан, потоа преку анализа на едно лично писмо што Х. Џ. Велс му го испраќа на Џојс во 1928 година, и, на крајот, преку спротивставената реакција на Т. С. Елиот во есејот Улис, йореgок и мий. Избраните искази ќе послужат како илустрација на двата спротивставени пола на книжевниот свет. Во вториот дел ќе го воведеме теоретскиот концепт йоле и неговиот специфичен дериват, йоле на книжевностй, на францускиот социолог Пјер Бурдје и спецификите на ова поле во рамките на полето на моќта. Во третиот дел ќе зборуваме за өвојнайа хиерархизаиија на книжевното поле и йрояук-

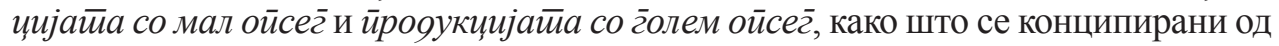
Бурдје, и преку овие концепти ќе ги анализираме исказот на Коелјо и писмото на Велс, како и реакцијата на Елиот. Во четвртиот дел, пак, ке покажеме што значат спротивставувањата од овој вид, гледани од аспект на продукцијата и репродукцијата на книжевното поле, во рамките на теоријата на Бурдје, и зошйо e воойшйо важно яа се яебайира за овие рабойи. Во последното поглавје ќе го сумираме изложеното во трудот во форма на заклучок.

\section{2 Џејмс Џојс наспроти „обичниот човек“}

Во 2012 година светски познатиот (и многу продаван) бразилски писател Пауло Коелјо дал изјава што го скандализирала книжевниот свет. Списанието Гаруијан вака го пренесе настанот:

Зборувајќи за бразилското списание Фолја gе С. Паоло, Коелјо рече дека причината за неговата популарност е тоа што е „модерен писател, без разлика на тоа што велат критичарите“. Тоа не значи дека неговите книги се експериментални; тој додаде: „Јас сум модерен бидејќи правам тешко да изгледа лесно и затоа можам да комуницирам со целиот свет.“ Според Коелјо, писателите грешат кога се фокусираат на формата, а не на содржината. „Денешните писатели сакаат да ги импресионираат другите писатели“, изјави за весникот. „Една од книгите што направи голема штета беше Улис на Џејмс Џојс, која е чист стил. Таму нема ништо. Соголена, Улис е само потсмев“" (Flood 2012). 
Понатаму во истата статија се потенцира дека делата на Коелјо се продадени во над 115 милиони копии во повеќе од 160 држави, додека романот Улис, објавен во 1922 година, бил со почетен тираж од само 1000 примероци. Сепак, тие илјада први изданија денес знаат да достигнат цена од околу 100.000 евра - со што се потенцира статусот на ова дело во историјата на книжевноста и во културата на Западна Европа. Во изјавата на Коелјо се искажани многу важни работи на кои подоцна ќе обрнеме внимание; само ќе потенцираме дека она што особено го привлече нашето внимание е критиката дека „денешните писатели сакаат да ги импресионираат другите писатели“", а како главен претставник за овој начин на книжевно производство е посочен романот Улис, „кој претставува чист стил“.

Доколку се вратиме речиси еден век наназад, ќе најдеме слични аргументи против делото на Џојс, но овојпат од тогаш мегапопуларниот политички активист, научен ентузијаст, прогресивец и еден од основоположниците на научнофантастичната литература, X. Џ. Велс. По повод едно од раните поглавја на Боеењетио на Финег̄ан - последниот роман на Џојс, чии извадоци циркулирале по книжевните списанија - тој во писмо директно го напаѓа Џојс и неговиот начин на пишување:

Јас имам огромна почит за вашиот гениј, кој може да се забележи уште во вашите најрани книги и чувствувам големо лично допаѓање кон вас; но, јас и вие сме тргнати во апсолутно различни насоки... А, што се однесува на вашиот книжевен експеримент... тој е значајна работа, бидејќи вие сте многу значаен човек и во вашиот натрупан состав вие поседувате моќен гениј за експресија, кој ѝ побегнал на дисциплината. Но, јас мислам дека тој не води никаде. Вие сте му го свртеле грбот на обичниот човек - на неговите основни потреби и на неговото ограничено време и интелигенција... Што е резултатот? Огромни загатки. Вашите две последни дела биле позабавни и повозбудливи да се напишат отколку да бидат читани. Земете ме како типичен обичен читател. Дали добив многу задоволство од ова дело? Не. Дали се чувствувам дека добивам нешто ново и илуминативно како што се чувствувам кога го читам ужасниот превод на Анреп на лошо напишаната книга на Павлов за условните рефлекси? Не. Затоа прашувам: кој по ѓаволите е овој Џојс, кој бара толку многу будни часови од преостанатите неколку илјади што сѐ уште ги имам, за правилно почитување на неговите каприци и фантазии и изблици на изведба? (Wells 2016)

И во ова писмо на Велс може да ги пронајдеме сличните забелешки како во изјавата на Коелјо. Џојс е обвинет дека „му го свртел грбот на обичниот човек“, дека пишува „огромни загатки“ преполни со „каприци и фантазии“ и, во крајна линија, дека е обземен со техниката на пишувањето (тоа што Коелјо го нарекува форма), а не со комуницирање на некоја значајна информација, разбирлива за сите (како „лошо напишаната книга на Павлов за условните рефлекси“). Повторно гледаме обвинување дека станува збор за дело што не е напишано за широката публика (,целиот свет“, „обичниот човек“), туку само за оние што можат да го разберат, односно писателите; тоа обвинение кај Коелјо е посочено експлицитно, додека во писмото на Велс останува имплицитно и може да се насети. Значајно е да ја споредиме реакцијата на Велс - кој сака да се претстави како „типичен, обичен читател“ во однос на Бяеењеейо на Финег̄ан - со прог- 
ласот на Т. С. Елиот во 1923 година дека е Улис „најважната експресија што модерното време ја има пронајдено; книга на која сите сме ѝ должници и од која никој од нас не може да побегне“ (Eliot 1975: 175,177). Елиот во никој случај не се поставува на местото на „обичниот читател“,, туку коментира од перспектива на уметник, кој му се обраќа на својот колега и го фали за „научното откритие“ што тој ѝ го подарил на книжевноста. Елиот е еден од тие писатели што биле импресионирани од ,загатките“ и ,каприците“ на Џојс и за кои модерните писатели - како што вели Коелјо - сакаат да пишуваат.

Историјата на книжевноста е полна со вакви контроверзии, дебати, контрирања, негирања и пофалби; понекогаш вмешаните учесници се од различен вид (писател кон критичар, публика кон писател, издавач кон писател, писател кон критичар итн.), ама релациите остануваат секогаш исти. Можеме да наброиме уште многу вакви примери; сепак, во корист на економичноста на овој труд ќе продолжиме со нашата анализа и ќе ги сметаме исказите на Коелјо, писмото на Велс и коментарите на Елиот како репрезентативни примероци за една типична ситуација на книжевнойо ӣоле..$^{2}$ Џојс е земен како идеален претставник на „писателот за писатели“, а Коелјо како идеален претставник на „писател што пишува за сите“. Велс, според нас, се наоѓа некаде помеѓу, но во писмото кон Џојс тој зазема гледна точка на „обичен читател“ и затоа неговите аргументи одат во корист на тоа што сакаме да го истражуваме. Единствено, сакаме да потенцираме дека изборот на преписката не се однесува на вмешаните учесници како индивидуи, туку на нивните меѓусебни односи, видот на аргументите што ги употребуваат и местоположбата што ја заземаат во книжевното поле. Станува збор за два спротивставени пристапи кон продукцијата на културни добра, една насочена кон мнозинството, а другата - кон малцинството; и двата генерирани

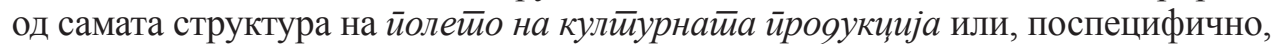
авйономнойо йоле на книжевносйа.

\section{3 Полето на книжевноста во теоријата на Пјер Бурдје}

Според францускиот социолог Пјер Бурдје, во општествената стварност постојат полуавтономни општествени простори, кои отстапуваат од генералната логика на општествениот живот и генералното поле на моќ и функционираат според свои закони, своја логика и, најважно од сѐ, своја економија. Ричард Џенкинс пишува:

\footnotetext{
${ }^{1}$ Елиот во повеќе книги се залага за „елитизам“ (во социополитичката смисла на зборот), наспроти либералнодемократската идеологија, како онаа на Велс. Елитата за него „претставува посвесна култура и поголема специјализација на културата“" (Eliot 1948: 110-121). Подлабока анализа на „елитизмот“ на Елиот во поглавјето Културна стратификаиија во Култура на Крис Џенкс (Jenks 2005: 94-114).

${ }^{2}$ Во недостиг на простор, би го насочил читателот кон уште два јасно артикулирани и репрезентативни примери: 1. Долгата дебата за природата на книжевноста меѓу Хенри Џејмс и X. Џ. Велс, во која Велс на сличен начин го критикува делото и начинот на пишување и размислување на Џејмс. Дебатата е документирана и анализирана во книгата Хенри Џејмс и X. ЏI. Велс: запис за нивното пријателство, нивната дебата за уметноста на фикиијата и нивната кавга, уредена од Едел и Pej (Edel and Ray 1958); 2. Есејот Реалноста во Америка од американскиот критичар Лајонел Трилинг, во која се анализираат спротивставените пристапи кон уметноста и животот во делата на писателите Теодор Драјзер и Хенри Џејмс - Драјзер како претставник на „обичниот човек“, а Џејмс како типичен „писател за писатели“ (Trilling 1953: 15-32).
} 
Полето, според Бурдје, е општествена арена во која се случуваат борби и маневри за специфични ресурси, влогови и пристап до нив. Полињата се дефинирани според видот на влогот - културни добра (,лајфстајл“), домување, интелектуална дистинкција (образование), вработување, земја, моќ (политика), општествена класа, престиж итн. - и можат да бидат со различни нивоа на специфичност и конкретност. Поради својата дефинирачка содржина, секое поле има различна логика и саморазбирлива структура на неопходност и релевантност, која е истовремено производ и производител на хабитусот што е специфичен и соодветен за полето (Jenkins 2006: 52) .

Полето (никогаш целосно изолирано и ослободено од полето на моќта) е полуавтономен микрокосмос, посебен свет со свои закони, логика на практиката, интересите и влоговите. Во македонскиот јазик зборот йоле може истовремено да значи „поле со цвеќиња“ и „воено поле“, што во голем дел ги доловува денотациите и конотациите што Бурдје сака да ги пренесе со овој збор. Имено, како што вели Патриша Томпсон, тој „не пишува за убави и бенигни les prés, туку повеќе за le champ, со што обично се опишува, inter alia, површина на земја, бојно поле, и поле на знаење“; оваа авторка, кога го дообјаснува концептот, ги употребува паралелите со фудбалскиот терен, со полето во научната фантастика (force field), па дури и со полето во физиката (Thompson 2008: 68). Неразделно поврзан со концептот 'поле' е концептот 'хабитус'. Полето го создава хабитусот на агентите, а потоа е репродуцирано

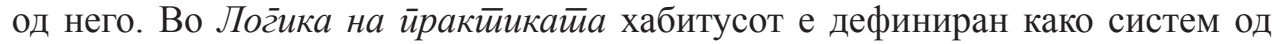
„трајни, подвижни диспозиции, структурирани структури предиспонирани да функционираат како структурирачки структури, односно како принципи што генерираат и организираат практики и претстави...“ (Bourdieu 1990: 53).

Под влијание на објективните структурни ограничувања (полето) и внатрешните „структурирани структури“ (хабитусот) интересот на агентите може да се предвиди. Тоа значи дека можеби дејствувањата на агентите како Коелјо, Велс, Џојс и Елиот - и покрај звучноста на нивните лични имиња - не се целосно идеосинкратични и непредвидливи. Под фразата „звучност на нивните имиња“" подразбираме една важна специфика на книжевното поле што мораме да ја потенцираме. Во целина, полето на културното производство е длабоко втемелно врз идеологијата на „култот и културата на 'личноста'“, идеологија што подразбира целосна автономија и неврзаност на агентите, кои, во овој случај, се занимаваат со производство на културни добра (Bourdieu 2010: 416). ${ }^{3}$ Потписот, односно личното име, во овој систем на вредности, а особено во полето на литературата, има квазимагична функција: истовремено го фетишизира уметничкото дело и го трансформира уметникот во „демијург“ (фраза на Бурдје), несводлив на мрежата на релации од кои ја добива својата „магична“" моќ (Bourdieu 1995: 230).

За Бурдје интересот што ги води агентите не може да се дефинира во општата смисла на зборот, туку секогаш конкретен интерес детерминиран

\footnotetext{
${ }^{3}$ „Литературата, во која, како што кажа Жид во својот Дневник, 'единствено личното има некаква вредност’, и славењето што го опкружува во книжевното поле и во образовниот систем, очигледно се централни за овој култ на себството, за кој филозофијата, обично сведена на возвишени потенцирања на дистинкцијата на мислителот, има значителен удел“ (Bourdieu 2010: 416).
} 
од полето: „Далеку од тоа да е некој вид антрополошка, природна даденост“, забележува тој, „интересот во својата историска спецификација е арбитрарна институција. Не постои интерес, туку интереси, варијабилни со времето и со просторот, речиси бесконечно: има исто толку интереси колку што има и полиња“. Со појавата на ново, специфично поле, додава Бурдје, се појавува и специјализиран интерес (Bourdieu 1994: 87). Агентите во полето се секогаш во потрага по специфичниот кайийал (симболички, општествен или културен) генериран од тоа поле; само ке посочиме дека симболичкиот капитал „да се направи име“ или ,да се стекне престиж“ е клучен влог за агентите што учествуваат во борбите и во натпреварите во книжевното поле (Bourdieu 1993: 75).

За да се нарече едно поле автономно, тоа треба да ја стекне или, подобро кажано, да се избори за својата автономија - книжевното поле тоа го има направено во текот на XIX век и таа автономија, некаде повеќе, некаде помалку, постои и функционира до ден-денес: од тие причини можевме да посочиме примери што се оддалечени во времето помалку од еден век (1993: 45). ${ }^{4}$ Во

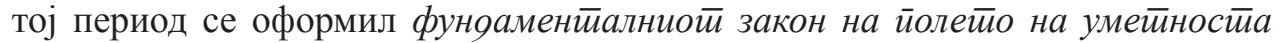

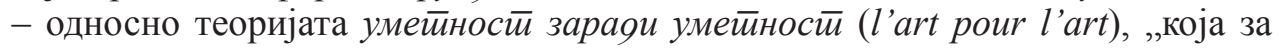
полето на културната продукција е тоа што аксиомата 'бизнисот е бизнис' (и 'во бизнисот нема простор за чувства') е за економското поле“ (1993: 62). Бурдје забележува дека „бизнисот на уметноста - односно во размената на ствари што немаат цена - ѝ припаѓа на класата на практики во која живее логиката на преткапиталистичката економија... Овие практики, функционирајќ́ како практични негации, единствено можат да функционираат ако се преправаат дека не го прават тоа што го прават... Тие можат да функционираат како практики и во перцепциите на агентите само преку константно и колективно потиснување на тесните 'економски' интереси...“" (1993: 72).

\section{1 Двојнайа хиерархизација на книжевното поле и йроgукииийе со мал

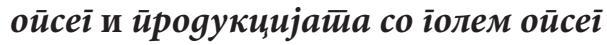

Агентите што се раководат исклучиво според автономните принципи на полето, единствено се заинтересирани за стекнување симболички капитал во вид на престиж, дејствување што е раководено според принципите на „безинтересна заинтересираност“, каде што уметноста е единствената цел по себе, а законите на пазарот и економската заработка воопшто не ги интересираат.

\footnotetext{
${ }^{4}$ Повеќе за автономијата на книжевното поле во првото поглавје од првиот дел на книгата на Бурдје Правилата на уметноста: Генезата и структурата на книжевното поле, насловено Освојување на автономијата: Критичната фаза во појавувањето на полето (1995: 47-113) Бурдје генерално зборува за француското книжевно поле, но, за споредба, го насочуваме читателот кон поглавјето Романтичниот уметник од делото на Рејмонд Вилијамс Култура $и$ општество: 1780-1950, каде што јасно е скицирана автономијата на книжевното поле во Англија (Williams 1960: 30-49).

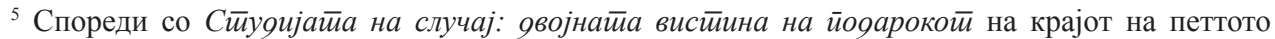
поглавје на Паскалијански меяитиации под наслов Симболичко насилсииво и йолитиччки борби, каде што Бурдје прави директна споредба меѓу културната продукција и општествената динамика на давањето и примањето подароци, како што ја опишува Марсел Moc (Bourdieu 2000: 191-202).
} 
Но, како што веќе рековме, ниедно поле, па така ни полето на книжевноста, не може целосно да биде одвоено и изолирано од генералните закони на општествениот простор; затоа, тоа е подложно на овојна хиерархизација. Од

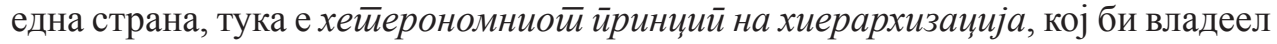
доколку полето би ја изгубило целата автономија и тогаш агентите би се однесувале како и сите други агенти во полето на моќта, каде што владее принципот дека „сѐ има цена“; економската придобивка е главниот поттик, а главниот судија е пазарот, односно тоа што Велс и Коелјо го нарекуваат „обичниот човек“. Од друга страна е принципот на авйономија на хиерархизацијайа, кој би владеел во поле со идеална и целосна автономија во однос на законийе на $\bar{u} а з а р о \bar{u}$ и капиталистичката логика: агентите во ваквото поле единствено би се стремеле кон акумулација на симболички капитал, односно йрестишж, кој потекнува од автономната логика на полето, а судии на успехот би биле другите произведувачи, односно другите уметници (1993: 38-39).

Оваа дистинкција се пресликува во опозицијата меѓу „комерцијалната“ и „некомерцијалната“ уметност. Станува збор за генеративниот принцип на книжевното поле, кој ги создава и ги раководи речиси сите дебати во уметничкиот свет (поле) и соодветните судови што се донесуваат за квалитетот или неквалитетот на уметничките дела. На овој начин се прави обид да се направи граница (дистинкција, разликување) меѓу „буржујската“ и „интелектуалната“", „авангардната“" и ,традиционалната““ уметност - a, во францускиот контекст - помеѓу левиоӣ и gесниоӣ брег̄ на Париз.

Секогаш станува збор за опозиција меѓу ӣрояукцијайа со мал ойсег̄ и продукцијата со г̄олем ойсег̄ (комерцијална продукција), односно меѓу првенството на производството и полето на производителите или дури и на супполето на производители за производители; и, на првенството на маркетингот, публиката, продажбата и успехот измерени квантитативно; меѓу одложениот, траен успех на 'класиците' и брзиот, привремен успех на бестселерите; меѓу производството втемелено на негирање на 'економијата' и на профитот (целите на продажбата итн.), кое ги игнорира или ги предизвикува очекувањата на етаблираната публика и не ѝ служи на ниедна друга побарувачка, освен на таа што самата ја создава (но, на долги патеки), и на производството што обезбедува успех и соодветен профит преку тоа што се приспособува на веќе постојната побарувачка (1993: 82). ${ }^{6}$

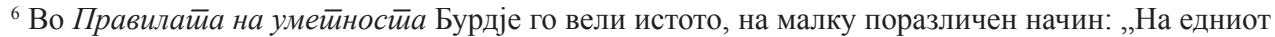
пол е 'антиекономската' економија на чистата уметност. Втемелена на задолжителното препознавање на вредностите на безинтересноста и на одрекување на 'економијата' (на 'комерцијалното') и на 'економскиот4 профит (на кратки патеки), го привилегира производството и специфичните неопходности што се исход на автономна историја." Ова производство, смета Бурдје, е насочено кон акумулација на симболички капитал, што можеби, потоа, на долги патеки ќе им овозможи и профит од економска природа. „На другиот пол е ‘економската’ логика на уметничките и книжевните индустрии, кои, бидејќ ја замислуваат трговијата на културни добра како и секоја друга трговија, го ставаат приоритетот на дистрибуцијата, на моментален и привремен успех, измерен, на пример, според испечатените примероци, и кои немаат проблем да се приспособат на веќе постојната побарувачка на клиентелата.“ На оваа поделба кореспон-

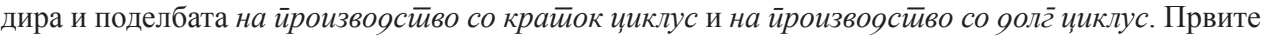
се подредени на економската, комерцијална логика, а вторите, на специфичната логика на книжевното поле (1995: 142). Бурдје му дава и темпорална димензија на производството; долгорочното е на страната на автономијата на полето, на акумулацијата на симболички капитал, име и
} 
Во полето постојано владее борба меѓу двата принципа на хиерархизација и меѓу продукцијата со мал опсег и продукцијата со голем опсег. Оние што сакаат да доминираат во полето политички и економски („буржујска уметност“) и оние што сакаат да владеат со автономните закони на полето (ларӣйурлар$\bar{u} u c \bar{u} u)$. Првите се во потрага по економски капитал, профит и политичка моќ, а вторите се раководат според специфичниот симболички капитал на полето, односно престижот, посветувањето (1993: 40). Без разлика на исходот, на полето постојано владее борба за да се наметне доминантниот модел на хиерархизација. Таа борба го определува значењето на успехот во полето, односно што значи успешен поет или романсиер. Со други зборови, борбата се сведува на тоа да се даде легитимна дефиниција на уметноста и на книжевноста и легитимна дефиниција на тоа што значи да се биде уметник и писател. Накратко, фундаменталниот влог на полето на книжевноста е „монополот за книжевната легитимност", inter alia, да се има моќта да се направи дистинкција меѓу писател и неписател, меѓу уметничко дело и неуметничко дело. „Границите на полето се влог во борбата“; целта на научникот, според Бурдје, не е да зазема страна, да биде pro или contra и самиот да почне да поставува граници, туку „да ја опише состојбата (долгорочна или привремена) на тие борби“" и границите на територијата на поединечните агенти (1993: 41-42).?

Дебатата меѓу Коелјо и (мртвиот) Џојс и меѓу Велс и (живиот) Џојс, како и поддршката на поетот критичар Елиот за Џојс, се типични релации и конфликти, производ и последица на самата структура на книжевното поле. Коелјо и Велс би биле претставници на хейерономниой иринций на хиерархизащија и йрояукиијайа со гоолем ойсег, а Џојс, во двата случаи, би бил претставник на авйономниой йринций на хиерархизащија и на йрояукцијайа со мал ойсег̄. Нивните конфликти се толку генерични што речиси совршено ја рефлектираат логиката на книжевното поле и тие, гледани како агенти, а не како лични имиња, заземаат можни позиции во рамките на објективно впишаната структура на полето и поради своите специфични хабитуси и општествени траектории (кои би биле интересна тема на друго истражување), ги заземаат токму тие позиции.

\section{4 Што значат дебатите од овој вид?}

Автентичниот придонес на Бурдје кон науката за книжевноста и социологијата на книжевноста не е во тоа што ја открил оваа спротивставеност ниту, пак, што покажал дека таа инхерентно произлегува од самата структура на полето. Важноста на неговата теоретска конструкција се наоѓa во нешто сосема друго и оригинално. Имено, тој забележува дека, иако двете позиции во рамките на книжевното поле се спротивставени, тие се длабоко и суштински поврзани токму преку нивната спротивставеност и потенцијал за „насочен конфликт“,

престиж; краткорочното е бестселерот, економскиот профит, хетерономијата на полето итн. Ја илустрира оваа опозиција во споредбата со француските издавачки куќи „Лафон“ и „Минуе“, со табела во која статистички се гледа што значи долгорочен успех, преку примерот на драмата Чекајќи го Гояо од Семјуел Бекет (1993: 97-98).

${ }^{7}$ „Неспоредливо полесно е да се заземе став за или против некоја идеја, некоја вредност, некоја личност или некоја ситуација, отколку да се анализира што е таа навистина, во сета нејзина сложеност“ (Бурдје 2006: 33). 
бидејќи тие дејствуваат „во форма на шеми на перцепција и разбирање што ги организираат сите перцепции во просторот на производители и производи“. Слично како во рамки на la langue на Де Сосир, идентитетот се добива негативно, единствено во однос и спротивставеност со другиот. ${ }^{8}$ На пример, уметникот маченик се дефинира токму наспроти уметникот што се откажал од автономијата на уметничкиот повик, а комерцијалниот уметник се дефинира токму наспроти уметникот што се отуѓил од стварноста на „обичниот човек“ и логиката на пазарната економија (1995: 166).

Ваквите дебати, ваквите спротивставувања, всушност, зад своите бескомпромисни и сурови препукувања го прикриваат и го потиснуваат она што им е заедничко на двата агенти во процесот на дебатата. „Борбата за монополот на легитимноста помага да се засили легитимноста на она во чие име се судираат“, забележува Бурдје. На тој начин, токму преку конфликтот, всушност, се потиснува прашањето зошйо воойшйо е важно gа се gебайира за овие рабой $и$ : „интересот и легитимноста на овие конфликти“ и на општествените предуслови што ги прават овие конфликти возможни. „Иако навидум безмилосни, овие конфликти го бранат она што е есенцијално: инвестираните убедувања на протагонистите.“ Така постојано се продуцира и се репродуцира illusio 9 на полето, „колективното придржување до играта, што е истовремено причина и последица за причината на играта“ (1995: 167). „Уметничките дела, како религиските добра или услуги, амајлиите и различните причести“ забележува Бурдје, ,jа добиваат својата вредност од колективната верба, како колективно погрешно препознавање, колективно создадено и репродуцирано“, на илузијата на полето, односно на „препознавање на играта и корисноста на играта, вербата во вредноста и влогот на играта“ (1995: 172-173). Со други зборови, она што Бурдје сака да го каже е дека дебатите не само што се последици на објективната структура на полето и субјективните диспозиции на агентите отелотворени во хабитусот туку дека тие, истовремено, преку самиот конфликт манифестиран во дебата за легитимитетот на тоа што треба да се смета за уметност, го создаваат и го репродуцираат книжевното поле како автономен микрокосмос во рамките на општествената стварност. Бурдје го користи терминот illusio не бидејќи сака да ја намали вредноста на

\footnotetext{
8, ,..Јазикот е систем од меѓузависни термини каде што вредноста на секој термин е одредена единствено преку симултаното присуство на другите термини“, забележува Сосир во Курс йo

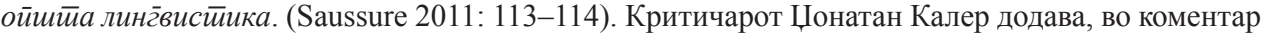
на ова тврдење на Сосир, дека „идентитетот е целосно во функција на разликата во системот“ (Culler 1976: 28).

${ }^{9}$ Во Паскалијански меяитаиии, Бурдје го дефинира овој поим на следниот начин: „Illusio сфатен како непосредно придржување до неопходноста на полето е многу малку веројатно да ѝ се појави на свеста, бидејќи во одредена смисла е исклучено од дискусијата... Illusio не припаѓa на редот на експлицитни принципи, на тези што се изнесуваат и се бранат, туку на редот на дејствувањето, рутината, работи што се направени, бидејќ се работи што вообичаено се прават и кои отсекогаш се правеле на тој начин“ (Bourdieu 2000: 102). Во овој контекст важно е да се забележи дека Бурдје за првпат го употребува терминот йоле токму во труд наменет за книжевноста („Champ intellectuel et projet créateur“) во однос на прочуената дебата меѓу книжевните критичари Ролан Барт и Рејмон Пикар. Имено, „Бурдје предлага дека, покрај нивните разлики, двајцата академици биле впуштени во слична академска работа: такви расправи биле дел од научничките практики и двајцата академци биле еднакво внесени во интринсичната вредност на оспорувањето и дебатирањето“ (Thompson 2008: 67-68).
} 
автономијата на книжевното поле, туку за да потенцира дека ова поле - како и сите други полиња, институции и интереси во рамките на општествената стварност - во својата суштина се арбийрарни. Со тоа единствено се потенцира дека тие се производ на историски, општествени и политички фактори и дека нивната суштина не е независна од пошироките историски и општествени процеси. Намерата на Бурдје во никој случај не е да ја намали вредноста на оваа илузија ниту, пак, да ја девалвира автентичноста на агентите што се борат за легитимноста на полето. ${ }^{10}$

Коментарите на Коелјо и писмата на Велс за тоа што претставува суштински уметноста, се дел од колективното потиснување на уметниците за самото прашање на легитимноста и важноста на книжевноста по себе. Токму тука се наоѓа и главниот методолошки проблем за проучување на уметничката и на книжевната стварност: „Постои специфична економија на книжевното и на уметничкото поле, втемелена на партикуларна форма на верба. Најголемите тешкотии лежат во потребата да се направи радикален пресек со оваа верба и со лажните сигурности на јазикот на славењето, без да заборавиме во процесот дека тие се дел од самата реалност што се обидуваме да ја разбереме и, како такви, тие мораат да го пронајдат своето место во моделот што е наменет за да ги објасни“, бидејќи самото „уметничко дело е објект што постои како таков единствено врз основа на (колективната) верба што го препознава и го признава како уметничко дело“ (Bourdieu 1993: 35). Научникот што се занимава со овие проблеми треба истовремено да ја избегне „славеничката возбуда“, која ќе го зароби и него во колективната илузија на фетишизирање, но да не потпадне под заводливоста на „редуктивната анализа“, која ќе ги сведе проблемите на еден друг терминолошки јазик, и нема суштински да го разбере влогот на полето и на агентите што го создаваат и го репродуцираат со нивната верба во влогот. Едниот пристап одбива да го види уметничкото дело како дел и производ на полето, а другиот пристап, пак, не ги гледа специфичностите на економијата на книжевното поле; една ригорозна наука за книжевноста, пак, мора најпрвин да го разбере уметничкото дело како фетиш, а потоа мора да земе предвид сѐ што помага да се втемели уметничкото дело како такво, а најмногу од сѐ, да го разбере и да го анализира тој славенички фетишистички дискурс (Bourdieu 1993: 35).

\section{5 Заклучок}

Во овој труд најпрвин ги анализиравме негативните коментари на писателите Пауло Коелјо и Х. Џ. Велс насочени кон делото на Џејмс Џојс, а од друга страна, ја дадовме позитивната евалуација на Улис од страна на Т.С. Елиот.

\footnotetext{
${ }^{10}$ Во неговите последни дела, особено во Протиивог̄нови, Бурдје изразува голема загриженост токму за нарушувањето на автономијата на полињата на културната продукција под силниот притисок на неолибералната економска логика: „Автономијата на универзумот на културната продукција во поглед на пазарот, која постојано се зголемуваше, преку борбите и жртвите на писателите, уметниците и на научниците, е сѐ повеќе и повеќе загрозена. Владеењето на 'трговијата' и 'комерцијалното' секој ден сѐ повеќе ѝ се наметнува на литературата, особено преку концентрацијата на издаваштвото, кое сѐ повеќе и повеќе директно ѝ се потчинува на принудата на непосредниот профит, на литературната и на уметничката критика, препуштена на најопортунистичките слуги на издавачите - или на нивните ортаци, со услугите ' јас - тебе, ти - мене', а особено на кинематографијата...“ (Бурдје 2006: 49).
} 
Овие четири автори ги зедовме како репрезентативни примероци на двата пола на полето на книжевната продукција: Велс и Коелјо како претставници на „обичниот човек“, а Џојс и Елиот како „писатели за писатели“. Понатаму ги изложивме теориите за книжевното поле и спецификите на тоа поле на францускиот социолог Пјер Бурдје и преку концептите на gвојнайа хиерархизација на книжевното поле и йрояукиијайа со мал ойсег и ирооукцијайа со г̄олем ойсег̄ ги анализиравме дискурсите на Коелјо, Велс и Елиот. Во последниот дел, пак, повторно користејќи се со теоретскиот апарат на Бурдје, се обидовме да дојдеме до продлабочени откритија во однос на тоа што значат дебатите од овој вид за книжевното поле, неговото конструирање и репродукција. Најпрвин забележавме дека дебатите се интринсични на полето на книжевната и културната продукција и дека потекнуваат од самата поларизираност на автономното поле и неговата релација со поширокото поле на моќ на кое припаѓа и од кое се развива; потоа забележавме дека овие дебати не само што природно произлегуваат од полето туку и дека агентите вмешани во нив и влоговите што се доведени во прашање се суштински за продукцијата и репродукцијата на самото поле. Односно, посочивме дека преку јавните и приватни конфликти на агентите вмешани во полето, се потиснува арбитрарноста на полето како автономно поле во рамките на општествената стварност и се обезбедува вербата во „играта“, нешто што е неопходно за самото функционирање на полето. Конфликтите од овој вид го одржуваат полето во живот и ја градат илузијата во свеста на агентите за историската арбитрарност на полето и дека конфликтите од овој вид се нужни и потребни - на тој начин автономијата на полето продолжува да постои.

\section{Библиографија}

Бурдје, П. (2006). Пройивог̄нови/За иеелевизијайа. Скопје: Темплум.

Bourdieu, P. (2010). Distinction: A Social Critique of the Judgment of Taste. London and New York: Routledge.

Bourdieu, P. (1990). The Logic of Practice. Stanford: Stanford University Press.

Bourdie, P., and Johnson. R. (ed.). (1993). The Field of Cultural Production: Essays on Art and Literature. New York: Columbia University Press.

Bourdieu, P. (1994). In Other Words: Essays Towards a Reflexive Sociology. Stanford, California: Stanford University Press.

Bourdieu, P. (1995). The Rules of Art: Genesis and Structure of the Literary Field. Stanford, California: Stanford University Press.

Bourdieu, P. (2000). Pascalian Meditations. Stanford: Stanford University Press.

Culler, J. (1976). Saussure. Great Britain, Glasgow: Fontana/Collins.

Edel. L., Ray. G. (1958). Henry James and H.G. Wells: A Record of their Friendship, their Debate on the Art of Fiction, and their Quarrel. London: Rupert Hart-Davis.

Eliot, T. S. (1948). Christianity and Culture. London: A Harvest Book.

Eliot, T.S. (1975). Ullysses, Order, and Myth. Kermode, F. (ed.). Selected Prose of T.S. Eliot. New York: Harcourt Brace Jovanovich.

Jenkins, R. (2006). Pierre Bourdieu. London and New York: Routledge.

Jenks, C. (2005). Culture. London: Routledge. 
Saussure, F. (2011). Course in General Linguistics. New York: Columbia University Press. Thompson, P. (2008). Field. In Grenfell, M. (ed.). Pierre Bourdieu: Key Concepts, 199-212. Durham: Acumen Publishing Limited.

Trilling, L. (1953). The Liberal Imagination: Essays on Literature and Society. New York: Doubleday Anchor Books.

Williams, R. (1960). Culture and Society: 1780-1950. New York: Anchor Books.

Flood, A. (2012). Paulo Coelho: James Joyce's Ulysses is 'harmful' to literature. Guardian. August 6th. [Online]. Available from: https://www.theguardian.com/books/2012/ aug/06/paulo-coelho-james-joyce-ulysses [Accessed: January 19th, 2021]

Wells, H.G. (2016). Who the hell is this Joyce?. The Paris Review. [Online]. September 28th. Available from: https://www.theparisreview.org/blog/2016/09/21/who-the-hell-is-this-joyce/ [Accessed: January 19th, 2021] 
